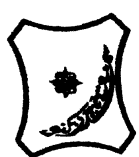

Bayero Journal of Pure and Applied Sciences, 10(2):

$251-255$

Received: June, 2017

Accepted: November, 2017

ISSN $2006-6996$

\title{
STUDY OF AVERAGE SEASONAL VARIATIONS OF SURFACE RADIO REFRACTIVITY ACROSS SOME SELECTED CITIES IN NIGERIA
}

\author{
Musa, B. ${ }^{1,2^{*}}$,Galadanci G.S.M ${ }^{2}$ Ayantunji B.G ${ }^{1}$, Mai-Unguwa $\mathbf{H}^{1}$, and Muhammad M. ${ }^{1}$ \\ ${ }^{1}$ National Space Research and Development agency, Abuja, Nigeria \\ ${ }^{2}$ Department of Physics and Electronics, Bayero University, Kano, Nigeria \\ *Correspondence author: mbgusau21@gmail.com, 08037260380, 07038017905
}

\begin{abstract}
The average seasonal variations of surface radio refractivity based on measurement of atmospheric pressure, temperature and relative humidity made across Yola ( $\left.9^{\circ} 11^{\prime} \mathrm{N}, 12^{\circ} 30^{\prime} \mathrm{E}\right)$, Anyigba ( $7^{\circ} 45^{\prime}$ $\left.N, 6^{\circ} 45^{\prime} E\right), L a g o s\left(6^{\circ} 27^{\prime} N, 5^{\circ} 12^{\prime} E\right)$, and Port-Harcourt (4 $\left.48 ' N, 7^{\circ} E\right)$ Nigeria, is reported. The measurement was made using wireless automatic weather station installed at the surface of each station under study. The study utilized three years of meteorological data measured from January 2010 to December 2013 to calculate the surface radio refractivity using empirical formula recommended by the International Telecommunication Union (ITU-R 453, 2012). The result shows that the average value of surface radio refractivity showed seasonal variations with high values during the rainy season and low values during the dry season with an increase in the value of surface radio refractivity of $242 \mathrm{~N}$-units at Anyigba station to a maximum value of $384-\mathrm{N}$ units at Lagos station. The result also shows that climatic condition is the force behind the seasonal variations of surface radio refractivity in all study stations.
\end{abstract}

Keywords: Refractivity, Temperature, Atmospheric pressure, Relative Humidity

\section{INTRODUCTION}

The effect of the earth's atmosphere, such as, absorption, depolarization, refraction, reflection, scattering etc., on radio waves propagating between earth and space is a constant concern in the design and performance of any communications systems. These conditions, when present alone or in combination on the earth-space link, can cause uncontrolled variations in signal amplitude, phase, polarization, and angle of arrival, which result in a reduction in the quality of analog transmissions and an increase in the error rate of digital transmissions. The quality of radio wave propagation in space communications depends on the frequency of operation, local climatology, local geography, type of transmission, and elevation angle to the satellite. In order to maintain the integrity of a communication link, the transmission medium is always a major source of compromise to the purity of the signal. When this medium is (or includes) the troposphere, it then becomes necessary to ensure that the signal can cope with tropospheric induced degradations arising from variations in temperature, relative humidity, atmospheric pressure, rain, atmospheric gases, etc. (Rotheram, 1989).

When radio waves are propagated through troposphere, multipath effect arises due to large scale variation in atmospheric refractive index, such as horizontal layers with very different refractivity. The effect becomes apparent when the same signal takes different path to its target, the ray arriving at different time and hence interfering with each other. The consequence of this larger scale variation in atmospheric refractive index is that radio wave propagating through troposphere becomes progressively curved towards the earth. Thus, range which is defined as the measure of deviation of refractive index, $\mathrm{n}$ of air from unity which is scaled-up of the radio waves is determined by the height dependence of the refractivity. Therefore, the refractivity of the earth atmosphere will not only affect the curvature of the ray path but also provide an insight into the fading phenomenon. (Adediji and Ajewole, 2010).

The influence of interference due to refractivity changes in the troposphere is much more in the tropical climate than in temperate climates because of the occurrence of high intensity tropical rainfall (Rotheram, 1989).

The effect of meteorological variable of pressure, temperature, and relative humidity on radio wave propagation at UHF and microwaves frequencies are analyzed from the study of radio refractive index derived from these three parameters (Bean and Dutton, 1966). Since these variables vary considerably daily and seasonally especially in the tropics, quantitative knowledge of refractivity variations is required in order to be able to design reliable and efficient radio communication (terrestrial and satellite) system. In radio propagation study, the troposphere is considered as a dielectric medium. The variations of the refractive index of the troposphere are small but nonetheless play an important role in radio wave propagation

The radio refractive index is defined as the ratio of the speed of propagation of radio energy in a vacuum to the speed in a specified medium (Bean and Dutton, 1966; Segal, 1985). Due to the minute difference between the value of refractive index in the troposphere (about 1.0003) and that of free space ( $n$ $=1.0$ ) it is more convenient to refer variations in refractive index in terms of a parameter called refractivity N (Thayer, 1974), 
in parts per million to obtain more amenable figures. Thus, $\mathrm{N}$ is dimensionless quantity defined as measured in $\mathrm{N}$ units (Hughest, 1998).

There are different techniques to measure the refractivity of air. Experiments to be described in this study utilize an indirect measurement, where the value of refractivity is obtained from the atmospheric pressure, temperature and water vapor pressure of the air using empirical formula provided by the International Telecommunication Union.

Several studies have been carried out around the world on electromagnetic wave medium interaction processes and the propagation implication. Example of these studies are: (Ayatunji, et al. 2011), (Okoro and Agbo,2012; Adediji, et al. 2013;Falodun and Ajewale, 2005; Kolawole and Owonubi, 1982; Kaissassou, et al. 2013; Ali, et al. 2011;Adeyemi and Kolawale, 1992; Hughes, 1993; Igwe and Adimula, 2009;Owolabi , et al. 1970; Kolawole, 1980 and Adediji and Ajewale, 2010).

This work presents the results of average seasonal variations of surface radio refractivity derived from the computation of atmospheric pressure, temperature and relative humidity using recommendation ITU-R 453 (ITU, 2012).

\section{Study Area}

Wireless automatic weather station installed at the surface of four selected stations in Nigeria viz; Yola $\left(9^{\circ} 11^{\prime} \mathrm{N}, 12^{\circ} 30^{\prime} \mathrm{E}\right)$, Anyigba $\left(7^{\circ} 45^{\prime} \mathrm{N}, 6^{\circ} 45^{\prime} \mathrm{E}\right)$, Lagos $\left(6^{\circ} 27^{\prime} \mathrm{N}, 5^{\circ} 12^{\prime} \mathrm{E}\right)$, andPort-Harcourt $\left(4^{\circ} 48^{\prime} \mathrm{N}, 7^{\circ} \mathrm{E}\right)$ were used for the measurement meteorological variables.

Nigeria lies between latitude $4^{\circ} \mathrm{N}$ and $14^{\circ} \mathrm{N}$ and longitude $2^{\circ} \mathrm{E}$ and $15^{\circ} \mathrm{E}$ respectively with a total area $N=\langle n-1\rangle \times 10^{-6}$

where $N$ is radio refractivity expressed by

$N=N_{d r y}+N_{w e t}=\frac{77.6}{T}\left(P+4810 \frac{e}{T}\right)$

with the 'dry term' of radio refractivity given by:

and the 'wet term' given by

$$
N_{d r y}=77.6 \frac{P}{T}
$$

$N_{w e t}=3.732 \times 10^{5} \frac{e}{T^{2}}$,

where: $\mathrm{P}$ is atmospheric pressure (hpa)

e is water vapor pressure (hpa) and

$\mathrm{T}$ is absolute temperature $(\mathrm{K})$

This expression may be used for all radio frequencies (for frequencies up to $100 \mathrm{GHz}$; the error is less than $0.5 \%$ ) for representative profiles of temperature, pressure and water vapour pressure (Babin et. al. 1997)

The water vapor pressure, e, can be calculated from relative humidity as

$\boldsymbol{e}=\frac{\boldsymbol{H} \boldsymbol{e}_{s}}{\mathbf{1 0 0}}$

(3)

where $e_{s}$ is defined as

$e_{s}=E F \cdot a \cdot \exp \left\{\frac{\left\langle b-\frac{t}{d}\right\rangle \cdot t}{t+c}\right\}$

and:

$$
E F_{\text {water }}=1+10^{-4}\left[7.2 P\left(0.00320+5.9 \cdot 10^{-7} \cdot t^{2}\right)\right]_{(5)}
$$

where $e_{s}$ is the water vapour partial pressure, $t$ is temperature in Celsius, $H$ is the humidity, and constants for water are $a=6.1121, b=18.678, c=257.14$ and $d=234.5$ (ITU-R, 2012).

\section{MATERIALS AND METHODS}

The indirect method of measuring refractivity was employed in this study. Surface values of pressure (hpa), Temperature $\left({ }^{\circ} \mathrm{C}\right)$, and Relative humidity (\%) were extracted from measurements made using Davis Vantage pro2 automatic weather station installed at

of 923,768 square kilometers. The country is located latitude of Nigeria falls within the tropical zone but climatic conditions are not entirely tropical in the country, in the north the climatic condition is arid and to the south there is an equatorial type of climate. The weather condition can be generally characterized into wet season, from April to October; soason, from November to March in the north and

\section{Relevant Theory}

refractive characteristics of the neutral mosphere (mainly troposphere) are governed by its are polar in nature; possessing manent dipole moment. All other gases are nonthese gases when microwave propagates xave causing a change in the refractive an important parameter in determining the quality of UHF, VHF and SHF signals. In characterizing a radio channel, surface (ground level) and elevated refractivity data are often required, and in particular,

According to ITU-R (2012), the atmospheric refractive 
Data collected from January 2011 to December 2013 were averaged over each hour to give twenty four data point representing diurnal variations for each day. The hourly data for each day is further averaged to give a data point for the day and the average was taken over the month to give a data point for each month which was used to determine the monthly variations for each year. The corresponding months for each year of the three years under study were then averaged to give the average seasonal variations for the period under study. The data were used to compute the surface radio refractivity using equations $2,3,4$ and 5 .

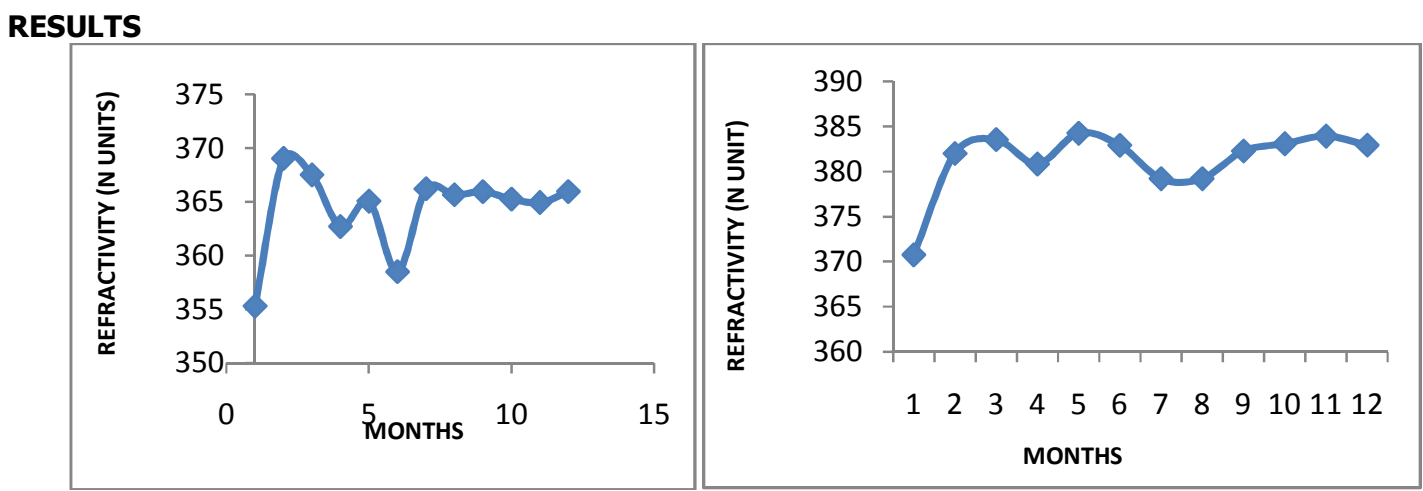

Fig. 1 Average Seasonal Variations of Surface Fig. 2 Average Seasonal Variations of Surface Radio Refractivity over Lagos from 2011 to 2013Radio

Radio Refractivity at Port-Harcourt from 2011 to 2013

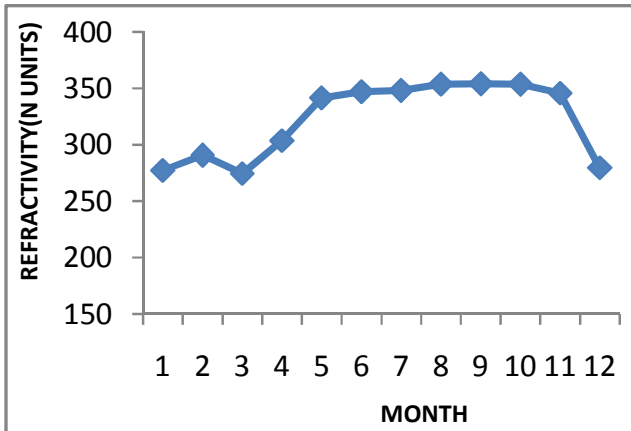

Fig. 3 Average Seasonal Variations of Surface Radio Refractivity over Yola from 2011 to 2013

\section{DISCUSSION}

Fig. 1, 2, 3 and 4 depict the average seasonal variations of surface radio refractivity over Lagos, Port-Harcourt, Yola and Anyigba, respectively, for the years under study. As observed from the figures, the values of radio refractivity were low during the dry months (November to March) at Anyigba and Yola, (November to February) at Lagos and Port-Harcourt. Minimum value of $370 \mathrm{~N}$-unit by January, $355 \mathrm{~N}$-unit by January, $242 \mathrm{~N}$-unit by August and $278 \mathrm{~N}$-unit by August were obtained at Lagos, Port-Harcourt, Yola and Anyigba respectively. Also observed from the figures the values of radio refractivity were high during rainy months (April to October) at Anyigba and Yola, (March to October) at Lagos and Port-Harcourt. Maximum value of $384 \mathrm{~N}$-unit by May, $366 \mathrm{~N}$-unit by July, $359 \mathrm{~N}$-unit by September and $361 \mathrm{~N}$-unit by September were obtained at Lagos, Port-Harcourt, Yola and Anyigba respectively.

The surface radio refractivity variations in Lagos and Port Harcourt as shown in Fig. 1 and Fig. 2 have high

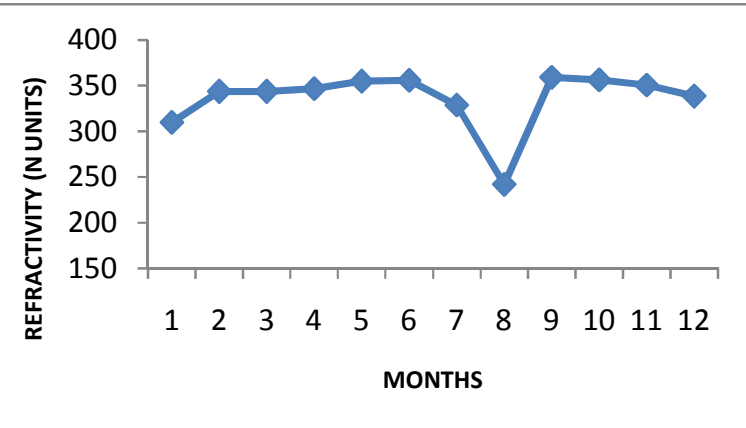

Fig. 4 Average Seasonal Variations of Surface Radio Refractivity over Anyigba from 2011 to 2013 values of refractivity when compared to other two stations. The variations of refractivity at these stations are erratic without any clearly defined pattern. The months of December to March are considered to be dry months in these study areas with reduced precipitation. The reduction in precipitation appears to have no effect on the value of refractivity in these locations. This is because the two stations are located along the coastal area and the influence of the Atlantic Ocean. A slight drop in the values of refractivity was observed in the months of April and July in these locations. The drop in April was attributed to the onset of rainy season while that of July was as a result of slight cessation of rainfall which is usually experienced in August in other locations and is referred to as August Break. The minimum value of refractivity was observed in the month of January which coincides with the peak of the harmattan season at both locations 
The harmattan season is associated with the northeasterly wind which passes over the Sahara desert with its attendance dryness. The minimum value at Lagos is $355 \mathrm{~N}$ units while that of PortHarcourt is $370 \mathrm{~N}$ units. The difference between the minimum and maximum values is $11 \mathrm{~N}$ units and $14 \mathrm{~N}$ units for Lagos and Port-Harcourt respectively. This results show that there is no much difference in refractivity value for the dry and rainy season at these locations. This observation can be attributed to the presence of the large water body (Atlantic Ocean) at Lagos and Port-Harcourt which makes the relative humidity to be consistently high. This result agrees with work of Ayatunji and Okeke, (2011).

Figures 3 and 4 depict the seasonal variations of refractivity at Yola and Anyigba respectively. The value of radio refractivity at these stations are generally low in the dry months (November to April) when compared with the values for rainy months. The minimum values of refractivity were also observed in January in these locations. The minimum value at Yola is $277 \mathrm{~N}$ units while it is $309 \mathrm{~N}$ units at Anyigba. The difference between the minimum and maximum for rainy and dry seasons were observed to be $76 \mathrm{~N}$ units for Yola and $50 \mathrm{~N}$ units for Anyigba. This shows that the influence of relative humidity is more pronounced at this location. The difference in variation between rainy and dry season values at Anyigba is lower than that of Yola. This is also attributed to the proximity of Anyigba to a large water body (Confluence of River Niger and Benue at Lokoja) which is less than $70 \mathrm{Km}$ away from Anyigba. A sudden and large drop was observed in Anyigba in the month of August which produced the lowest value of refractivity. This is attributed to August break. This

\section{REFERRENCES}

Ali, S., Malik, S. A., Alimgeer, K. S., Khan, K. S. and Ali, R. L., (2011). Statistical estimation of tropospheric radio refractivity derived from 10 years meteorological data, Journal of atmospheric and solar-Terrestrial physics, Vol. 77, pp 196-103

Adediji, A. T. and Ajewole, M. O., (2010). Microwave Anomalous Propagation (AP) Measurement over Akure South-Western Nigeria, Journal of atmospheric and solar-Terrestrial physics, vol. 72, pp 550-555.

Adediji, A. T., Ajewole, M. O. and Falodun, S. E., (2011). Distribution of radio refractivity gradient and effective earth radius factor (k-factor) over Akure, South Western Nigeria, Journal of atmospheric and solarTerrestrial physics, vol. 73, pp 2300-2304

Adediji, A. T., Mahamod, I. and Mandeep, J. S., (2013). Variation of radio field strength and radio horizon distance over three stations in Nigeria, Journal of atmospheric and solar-Terrestrial physics, vol. 109, pp 1-6

Ayatunji, B. G. and Okeke, P. N., (2011). Diurnal and seasonal variation of surface refractivity over Nigeria, Progress in electromagnetic Research B, vol. 30, pp 201-222 phenomenon was not observed in Yola. Anyigba is not in the rain forest zone, but the climatic pattern of Anyigba is nearly the same due to its proximity to the zone. This result agrees with the work ofAyatunji and Okeke (2011), Owolabi and Williams (1970) and Oyedum et al., (2010).

Results from this study show that the climatic condition is the main driver of seasonal variations of refractivity.

\section{CONCLUSION}

The major findings of this study are as follows:

Refractivity reveals seasonal variations with high values in the rainy season and low values in the dry season over all the locations.

Refractivity values computed for the locations under study increases from about $242 \mathrm{~N}$ - units at Anyigba northern Nigeria to 384 N-units at Port-Harcourt southern Nigeria.

- The seasonal variation of refractivity of the troposphere is a function of climatic condition as observed from the results obtained from the study locations.

\section{ACKNOWLEDGEMENT}

The research group acknowledged the effort of the NASRDA, Center for Atmospheric Research under the project, Tropospheric Data Acquisition Network (TRODAN) and Centre for Basic Space Science, University of Nigeria, Nsukka for providing the database for characterization of the troposphere over Nigeria for prediction of impairment for microwave communication.

Ayatunji, B. G., Okeke, P. N. and Urama, J.O., (2011). Seasonal variation of surface refractivity over Nigeria, Advances in space Research vol. 48, pp 2023-2027

Adeyemi, R. A. and Kolawole, L. B., (1992). Seasonal and Diurnal Variations of Surface Refractivity in Akure, South-Western Nigeria, Unpublished M.Sc Thesis, department of Physics, Federal University of Technology, Akure, Nigeria.

Bean, B. R., Dutton, E. J., (1966). Radio Meteorology, Dover Edition, New York, USA, 1-20.

Babin, S. M., Young, G. S. and Carton, J. A., (1997). A new model of the oceanic evaporation duct, Journal of Applied Meteorology, Vol. 36, pp 193- 204.

Falodun, S. E. and Ajewole, M.O., (2005). Radio refractive index in the lowest $100 \mathrm{~m}$ layer of the troposphere in Akure, South-western Journal of atmospheric and solar-Terrestrial Physics, Vol. 68, Pp 236 - 243.

Hughes, K. A., (1993). Radio Propagation Data from Tropical Regions: A Brief Review of a seminar on Radio Propagation in Tropical Regions, An unpublished lecture note presented at Centre for Theoretical Physics, Trieste (Italy). 
ITU - R., (2012). The refractive index: its formula and refractivity data, Recommendation 203/1, ITU-R, Pp 453:10.

Igwe K .C. and Adimula, I. A., (2009). Variation of surface radio refractivity and radio refractive index gradient in sub-sahel, Nigeria journal of space research, vol. 6, pp 135-144.s

Kaissassou, S., Lenouo, A., Tchawoua, C., Lopez, P. and Gaye, A. T., (2014). Climatology of radar anomalous propagation over West Africa, Journal of atmospheric and solarTerrestrial physics.

Kolawole, L. B., (1980). Climatological Variation of Surface Refractivity in Nigeria, Nigeria Institute of Physics, Vol. 4, Pp 97-117.

Kolawole, L. B., and Owonubi, J. J., (1982). The Surface Radio Refractivity Over Africa, Nigerian Journal of Science, Vol. 16, Nos. 1 \& 2, Pp 441-454.

Owolabi, I. E. and Williams, V. A., (1970). Surface Radio Refractivity Pattern in Nigeria and Southern Cameroon, Journal of West African Science Association, Vol. 20, No. 1, Pp 3-17
Okoro, O. N. and Agbo, G. A., (2012). The effect of variation of meteorological parameters on tropospheric radio refractivity for minna, Global journals inc., (USA).

Oyedum, O. D., Igwe, K. C., Eichie, J. O., Moses, A.S., (2010). Preliminary results of surface refractivity in Minna, Niger State, Nigeria, Proceedings of Annual Conference of Nigerian Union of Radio Science, Pp 20, 28.

Rotheram, S., (1989). Clear air aspects of the troposphere and their effects on propagation mechanisms from VHF to millimeter waves, Radiowave Propagation, Peter Peregrinus Ltd., pp. 150-153.

Segal, B., (1985). Measurement of tropospheric refractive index relevant to the study of anomalous microwave propagation- review and recommendations, CRC Report No. 1387.

Thayer, G. D., (1974). An improved equation for radio refractive index of air, Radio Science, Vol. 9, No. 10, Pp $803-807$. 